\title{
環境振動設計支援のための床スラブ簡易解析手法 A SIMPLIFIED ANALYSIS PROCEDURE TO AID DESIGN OF FLOOR SLABS FOR ENVIRONMENTAL VIBRATION
}

\author{
加藤 泰正*, 本間俊雄**, 井口道雄*** \\ Yasumasa KATO, Toshio HONMA and Michio IGUCHI
}

\begin{abstract}
In order to aid design for environmental vibration, a simplified analysis for a floor slab is presented. The floor slab is supposed to be rectangular orthotropic Mindlin plates with Timoshenko beams. Then, the Rayleigh-Ritz method is adopted using Timoshenko beam functions with elastic restraint against translation and rotation as admissible functions. Since point supports are also considered, it is possible to create appropriate boundary conditions. Furthermore, a moving load and SMD (Spring-Mass-Dashpot) system are taken into account to stand for a moving body on the floor slab such as a forklift.

Through a few numerical examples, some characteristics of the effective mass of Mindlin plate were examined to aid design for a TMD (Tuned Mass Damper). And dynamic effects caused by a moving load were found to be comparatively large when the plate was supported at only four corner points.
\end{abstract}

Keywords : floor vibration, the Rayleigh-Ritz method, Mindlin plate, effective mass, spring-mass-dashpot system, moving load 床振動，レーリー・リッツ法，ミンドリン平板，有効質量，バネ・マス・ダッシホポ孫，移動荷重

\section{1. はじめに}

近年の構造技術の進歩が床スラブの大スパン化を可能とし、建築空 間の有効利用が図られる一方、環境振動対策としての床スラブ設計が 重要になっている 1。設計を支援するための床振動予測は数值解析に よるが、その予測精度を向上させるためには現実に即したモデル化が 必要であり、種々の境界条件、梁付スラブ、床スラブのせん断変形、 振動低减を目的とした $\mathrm{TMD}^{2}$ ( Tuned Mass Damper )等を考慮すること が重要である。また、設計で想定する外力の対象として、建屋内で振

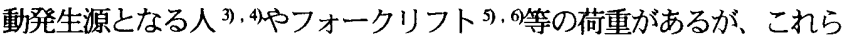
の荷重は実際には床スラブ上を水平方向に移動することが多く、移動 荷重として取り扱う必要がある。

移動荷重に対する鈆直振動の問題は、道路橋や鉄道橋の設計分野に おいて多くの研究か報告されているわ,の。こような橋梁の基本的な解 析モデルとしては、橋杵は両端ピン支持した Bernoulli-Euler 仮定下の 梁、移動車両は質量を無視した一定速度の移動荷重と表現したものが 多い。このタイプのモデルでは運動方程式の解として級数解が与えら れているが、それは単純な支持条件の場合に限定される9。あるいは また、移動車両をより現実的にモデル化するために SMD (Spring-MassDashpot)系の移動として、梁の振動と連成させることがあり、その解 法としては主に Rayleigh-Ritz 法や FEM (Finite Element Method)等の数值

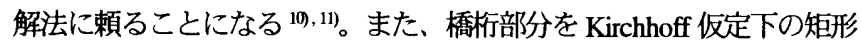
異方性板、移動車両をバネとマスで表現し、平板の相対する境界がそ れぞれ単純支持及び自由端の条件で級数解を示した研究もある ゅ。近 年では、移動荷重の問題に対して精密なモデル化を試みるという観点 から、Timoshenko 梁 ${ }^{13 、}$ 、梁に対する種々の支持条件 ${ }^{14)}$ 、平板に対す る移動質量の時間变化 ${ }^{15}$ 等の条件を採り入れた研究がある。しかし、 床スラブ設計を対象として平板を四隅点支持するような現実的な境界 条件の元、移動荷重による動的効果を調べた研究は著者等の知る限り 無い。

一方、構造設計者が休振動の予測・評価を行う場合、公式化された 平板の理論解や FEM がよく利用される。しかし、平板の理論解は条 件設定に種々の制約があり、実際の床スラブを精度良くモデル化する のが容易ではない。FEM においては、詳細な解析モデルを構築でき るが、扱うデー夕量が膨大となり、計算結果を得るまでに多大な労力 と時間を要する等の難点がある。こうした背景の元、著者等は平板の 理論解と FEM の中間に位置する Rayleigh-Ritz 法による矩形平板の

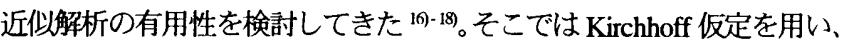
扱える主な条件は、(1)材料の直交異方性、(2)梁による補強、(3)周辺境 界の弾性バネ支持、(4)任意点の弾性バネ支持、(5TMD による振動制 御、6移動荷重、である。こうした条件の導入により、実際の床スラ

\footnotetext{
* (侏)フジ夕技術研究所

** 鹿先島大学: -1学部建築学科 助教授・工博

*** 東京理科大学理工学部建築学科 教授・ 工辇
}

Technical Research Institute, Fujita Corporation

Assoc. Prof., Dept. of Architecture \& Architectural Eng., Faculty of Engineering, Kagoshima Univ., Dr. Eng.

Prof., Dept. of Architectural Engineering, Faculty of Science and Engineering, Science Univ. of Tokyo, Dr. Eng. 
ブを精度良くモデル化することができ、実測值との比較結果も良好で、 その実用性を確認している。この近似解析では、扱うデー夕量が少な く、計算時間も短いため、ユーザは容易に多くの解析経験を積み重ね ることができる。こうした利点は解析ノウハウの形成を促進する。そ れをマニュアル化して蓄積することにより、知識の共有化へと結び付 けることができ、幅広く設計支援することが可能となる。

本研究では、床スラブをより忠実にモデル化できるようにせん断変 形を考虑した Reissner-Mindlin 理論 ${ }^{19,29)}$ を採用し、上記(1)〜6及びSMD 系の平板上の水平移動を考虑する。前述したように、移動荷重に対し て床スラブの鈶直振動を抑制し、居住環境や精密機械の動作環境を確 保するための瑥境振動の設計を行なうことは重要である。本論文は、 そのような設計の支援を意図した Rayleigh-Ritz 法による簡易な解析手 法を提案することを目的としている。また、平板の境界条件として、 自由端、単純支持、固定支持、及びそれらの中間の固定度を任意に表 わすために、両端バネ支持した Timoshenko 梁関数を工夫して形状関 数に用いる。計算例としては、休スラブの有効質量、及び、移動物体 を考慮した床スラブの時刻歴応答を示す。TMD の設計ではその装置 が有する振動数の調整範囲に制限があるため、事前に床スラブの有効 質量を精度良く予測する必要がある。移動物体の問題では、これまで 床振動応答の計算時に省略されることが多かった移動物体の速度ある いは SMD系の特性が、条件によっては無視できないことを示す。

\section{Rayleigh-Ritz 法による Mindlin 平板の振動解析}

㦿スラブを矩形の Mindlin 平板として解析するに当たり、適用範囲の昖張 のため、次の条件を考慮する。

(1) 材料の直交異方性

(2) Timoshenko 梁の任意配置

(3) 一様な鈶直（板㫗方向）及ひ回転バネによる周辺境界の弾性支持

(4) 鈶直及び回転バネによる任意点の弾性支持

(5) SMD 系の水平移動

(6) 加振力の水平移動

(1) U 字形のデッキプレートを使用した木スラブやボイドスラブ等のよ うにスラブ部分の剛性に方向性がある場合に利用する。(2)は実際の梁の位 置においてその剛性と重量を考慮する。(3は周辺境界のバネ剛性を変化さ せることにより、固定支持、単純支持、自由端、あるいは、それらの中間 の固定度を表現できるようにする。(4)は柱位置での床スラブの点支持を表 わす。(3)と(4)を組み合わせることで、実状に適した境界条件が設定できる。 (5)は休スラブ上を水平移動する物体、すなわち、人やフォークリフト等を 表わす。 TMD は SMD 系が水平方向に静止している状態を考えればよい。 (6)移動物体からの加振力を意味する。種々の加振力が計測されており かーケ、 それらを利用できるようにする。

\section{1 解析モデル}

解析モデルの概要を Fig1 (a), (b)に示す。(a)は上述した条件(5),6、(b)は条 件(2)（4)の内容に対応している。各境界は鈶直バネ剛性 $K_{A}, K_{B}, K_{C}, K_{D}$ 及 ひ回転バネ凪性 $R_{A}, R_{B}, R_{C}, R_{D}$ を有し、直線上に一様分布するバネで弾 性支持される。各バネ剛性の右下の添え字は境界の場所を示しており、 それぞれ境界 $\mathrm{A}(x=0)$ 、境界 $\mathrm{B}(x=a)$ 、境界 $\mathrm{C}(y=0)$ 、境界 D $(y=b)$ である。点支持に関しては鈶直バネ剛性 $K$, 及ひ回転バネ剛性 $R_{y r}\left(x\right.$ 軸回り), $R_{x}$ （ $y$ 軸回り）を有するバネにより座標 $\left(x_{r}, y_{r}\right)$ で弾 性支持される。Timoshenko 梁は $x, y$ 軸にそれぞれ平行または各軸上

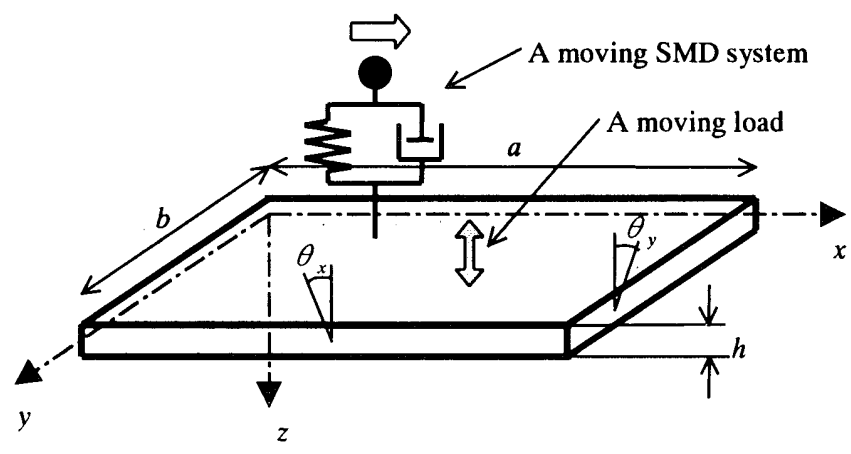

(a) Mindlin plate with moving loads and spring-mass-dashpot systems

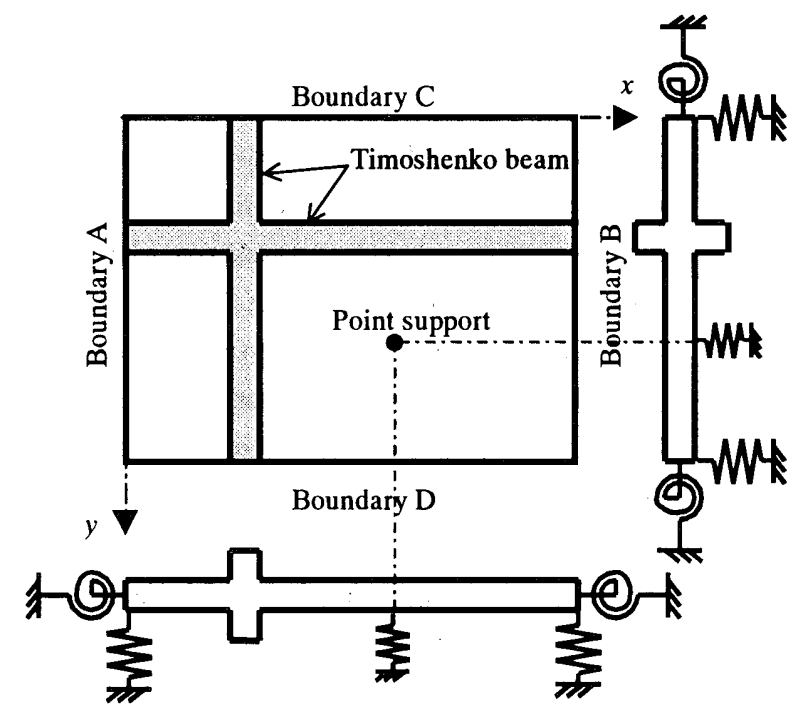

(b) Stiffened Mindlin plate with elastic restraint against translation and rotation, and point supports

Fig.1 Analytical model in this study

に配置される。 $y$ 軸に平行な梁は $x=x_{p}$ の線上に配置され、曲け剛性 $E_{p} I_{p}$ 、 せん断剛性 $\kappa_{p} G_{p} A_{p}$ 、ねじり剛性 $G_{p} J_{p}$ を持つ。同様に、 $x$ 軸に平行な梁 は $y=y_{q}$ の線上に配置され、曲け剛性 $E_{q} I_{q}$ ，せん断用性 $\kappa_{q} G_{q} A_{q}$ 、ねじり 剛性 $G_{q} J$ 存持つ。梁断面の図心板の中央面に一致するように配置さ れる。SMD 系は座標值 $\left(x_{s}(t), y_{s}(t)\right)$ に設置され、バネ剛性 $k_{s}$ 、質量 $m_{s}$ 及び減衰俰数 $c_{s}$ を持つ。 $x_{s}(t), y_{s}(t)$ はそれぞれ時間 $t$ の関数で表わされ た $x, y$ の座標值を意味する。水平方向に移動する集中荷重は座標值 $\left(x_{c}(t), y_{c}(t)\right)$ に作用し、その大きさも $p_{c}(t)$ と時間の関数で与えられる。 なお、添え字 $p, q, r, s, c$ は級数の指標で $1,2,3 \ldots$ を意味する。

\subsection{Rayleigh-Ritz 法の適用}

SMD 系及び Timoshenko 梁を付加した直交異方性を有する矩形 Mindlin 平 板の最大歪エネルギーUは次式のように表わされる。

$U=\frac{1}{2} \int_{0}^{b} \int_{0}^{a}\left\{D_{x}\left(\theta_{x},{ }^{2}+v_{x y} \theta_{y}, \theta_{y} \theta_{x}\right)+D_{y}\left(\theta_{y},{ }_{y}{ }^{2}+v_{y x} \theta_{x}, \theta_{x} \theta_{y},{ }_{y}\right)\right.$

$\left.+D_{x y}\left(\theta_{x},{ }_{y}+\theta_{y},_{x}\right)^{2}+\kappa h G_{x}\left(w,_{x}+\theta_{x}\right)^{2}+\kappa h G_{y}\left(w,_{y}+\theta_{y}\right)^{2}\right\} d x d y$

$+\frac{1}{2} \sum_{p=1}\left\{E_{p} I_{p} \int_{0}^{b} \theta_{y},\left.y_{y}^{2}\right|_{x=x_{p}} d y+\kappa_{p} G_{p} A_{p} \int_{0}^{b}\left|w, y_{y}\right|_{x=x_{p}}+\left.\theta_{y}\right|_{x=x_{p}}\right\}^{2} d y$ $\left.+G_{p} J_{p} \int_{0}^{b} \theta_{x},\left._{y}^{2}\right|_{x=x_{p}} d y\right\}$ 
$+\frac{1}{2} \sum_{q=1}\left\{E_{q} I_{q} \int_{0}^{a} \theta_{x},\left.{ }^{2}\right|_{y=y_{q}} d x+\kappa_{q} G_{q} A_{q} \int_{0}^{a}\left(w,\left._{x}\right|_{y=y_{q}}+\left.\theta_{x}\right|_{y-y_{q}}\right)^{2} d x\right.$ $\left.+G_{q} J_{q} \int_{0}^{a} \theta_{y},\left.{ }_{x}^{2}\right|_{y=y_{q}} d x\right\}$

$+\left.\frac{1}{2} K_{A} \int_{0}^{b} w^{2}\right|_{x=0} d y+\left.\frac{1}{2} R_{A} \int_{0}^{b} \theta_{x}^{2}\right|_{x=0} d y+\left.\frac{1}{2} K_{B} \int_{0}^{b} w^{2}\right|_{x=0} d y+\left.\frac{1}{2} R_{B} \int_{0}^{b} \theta_{x}^{2}\right|_{x=0} d y$ $+\left.\frac{1}{2} K_{C} \int_{0}^{a} w^{2}\right|_{y-0} d x+\left.\frac{1}{2} R_{C} \int_{0}^{a} \theta_{y}^{2}\right|_{y-0} d x+\left.\frac{1}{2} K_{D} \int_{0}^{a} w^{2}\right|_{y-b} d x+\left.\frac{1}{2} R_{D} \int_{0}^{a} \theta_{y}^{2}\right|_{y-b} d x$ $+\frac{1}{2} \sum_{r=1}\left\{\left.K_{r} w^{2}\right|_{\left(x_{r}, y_{r}\right)}+\left.R_{y r} \theta_{y}^{2}\right|_{\left(x_{r}, y_{r}\right)}+\left.R_{x r} \theta_{x}^{2}\right|_{\left(x_{r}, y_{r}\right)}\right\}+\frac{1}{2} \sum_{s=1} k_{s} w_{s}^{2}$

ただし、 $D_{x}=E_{x} h^{3} / 12\left(1-\nu_{x y} \nu_{y x}\right), D_{y}=D_{x} E_{y} / E_{x}, D_{x y}=G_{0} h^{3} / 12$ は異方性板 の曲倜性性を表わす。 $G_{0}=\left(E_{x} E_{y}\right)^{12} / 2\left(1+\left(\nu_{x y} \nu_{y x}\right)^{12}\right), G_{x}, G_{y}$ は異方性板の せん断弹性係数を表わす。 $h$ は板厚、 $\kappa$ は有効せん断倸数、 $E_{x}, E_{y}$ はそ れぞれ $x, y$ 方向のヤング保数、 $\nu_{x y}, \nu_{y x}$ はポアソン比を表わす。 $w$ は 板のたわみ、 $w_{s}$ は SMD 系のバネの変形量(板に関する相対変位)であ る。記号 ( $)_{x}$ は $x$ 方向の微分を意味する。

平板上を水平方向に移動する集中荷重のポテンシャルエネルギー $W$ は次式で与えられる。

$$
W=\left.\sum_{c=1} p_{c}(t) w\right|_{\left(x_{c}(t), y_{c}(t)\right)}
$$

一方、最大運動エネルギー $T$ は時間に関して調和振動を仮定すれば 次式で与えられる。

$$
\begin{aligned}
T & =\frac{1}{2} \omega^{2}\left(\rho_{0}+\rho_{m}\right) \int_{0}^{b} \int_{0}^{a}\left\{h w^{2}+\frac{1}{12} h^{3}\left(\theta_{x}^{2}+\theta_{y}{ }^{2}\right)\right\} d x d y \\
& +\frac{1}{2} \omega^{2}\left[\left.\sum_{p=1} \rho_{p} \int_{0}^{b}\left\{A_{p} w^{2}+I_{p}\left(\theta_{x}{ }^{2}+\theta_{y}{ }^{2}\right)\right\}\right|_{x=x_{p}} d y\right. \\
& \left.+\left.\sum_{q=1} \rho_{q} \int_{0}^{a}\left\{A_{q} w^{2}+I_{q}\left(\theta_{x}{ }^{2}+\theta_{y}{ }^{2}\right)\right\}\right|_{y=y_{q}} d x\right] \\
& +\frac{1}{2} \omega^{2} \sum_{s=1} m_{s}\left(\left.w\right|_{\left(x_{s}(t), y_{s}(t)\right)}+w_{s}\right)^{2}
\end{aligned}
$$

ただし、 $\omega$ は円振動数、 $\rho_{0} ， \rho_{m}$ はそれそぞれ板の質量密度、単位面積 当たりの付加質量密度を意味する。

よって、本振動系における総エネルギー $\pi$ は式(1)〜(3)より、次のよ うに表わされる。

$$
\pi=U-T-W
$$

次に、平板のたわみ及び曲げ変形に対応する回転角を次のように展 開する ${ }^{21)}$

$$
\begin{aligned}
& w(x, y)=\sum_{m=1} \sum_{n=1} w_{m n} f_{x m}(x) f_{y n}(y) \\
& \theta_{x}(x, y)=\sum_{m=1} \sum_{n=1} \theta_{x m n} g_{x m}(x) f_{y n}(y) \\
& \theta_{y}(x, y)=\sum_{m=1} \sum_{n=1} \theta_{y_{m n}} f_{x m}(x) g_{y n}(y)
\end{aligned}
$$

ただし、 $f_{x m}(x), g_{v n}(x)$ はそれぞれ $x$ 方向の、 $f_{y n}(y), g_{y n}(y)$ はそれぞれ $y$ 方 向の形状関数であり、幾何学的な境界条件を満足した関数が選ばれる。 $w_{n n}, \theta_{x m n}, \theta_{y m n}$ はそれぞれ未定係数を意味する。

式(4)に式(5)を代入し、次のエネルギーの停留条件により、上記の未 定係数を得る。

$$
\frac{\partial \pi}{\partial w_{m n}}=\frac{\partial \pi}{\partial \theta_{x m n}}=\frac{\partial \pi}{\partial \theta_{y m n}}=0
$$

自由振動解析の場合は、式(4)において外力によるポテンシャルエネ
ルギーWの項を削除する。時刻歴応答解析の場合は文献 15), 16)に示す 减衰マトリクスを作成し、Newmark- $\beta$ 法を採用して逐次計算を行なう。 SMD 系が平板上を水平移動する時は、マス・マトリクスが時間毎に 変化し、逐次逆マトリクスを計算する必要がある。しかし、RayleighRitz 法を用いているため扱う自由度数が少なく、結果を得るのに大き な障害とはならない。

\subsection{Timoshenko 梁関数}

式(5)で用いる形状関数には、両端を鈶直及び回転バネで支持された Timoshenko 梁関数を用いる。まず、梁の長さ方向を $x$ 軸方向とすると、 梁の固有振動モード形を表わすたわみ $W_{b}$ 及び曲げ変形に対応する回 転角 $\Theta_{x}$ は次式のように与えられる2723。

$$
\left.\begin{array}{l}
W_{b}=C_{1} \sin \frac{p_{0} x}{L}+C_{2} \cos \frac{p_{0} x}{L}+C_{3} \sinh \frac{q_{0} x}{L}+C_{4} \cosh \frac{q_{0} x}{L} \\
\Theta_{x}=C_{1} k_{1} \cos \frac{p_{0} x}{L}-C_{2} k_{1} \sin \frac{p_{0} x}{L}+C_{3} k_{2} \cosh \frac{q_{0} x}{L}+C_{4} k_{2} \sinh \frac{q_{0} x}{L}
\end{array}\right\}
$$

ここに、 $C_{1}, C_{2}, C_{3}, C_{4}$ は未定係数であり、その他の記号の意味は次の 通りである。

$$
\left.\begin{array}{l}
2 p_{0}{ }^{2}=b_{0}^{2}\left(r_{0}{ }^{2}+s_{0}{ }^{2}\right)+\sqrt{b_{0}^{4}\left(r_{0}{ }^{2}-s_{0}{ }^{2}\right)^{2}+4 b_{0}^{2}} \\
2 q_{0}{ }^{2}=-b_{0}^{2}\left(r_{0}{ }^{2}+s_{0}{ }^{2}\right)+\sqrt{b_{0}^{4}\left(r_{0}{ }^{2}-s_{0}{ }^{2}\right)^{2}+4 b_{0}^{2}}
\end{array}\right\}
$$

$\rho$ : 質量密度, $\omega_{n}$ : 固有円振動数, $A_{b}$ : 断面積, $L$ : 材長,

$E_{b}$ : ヤング係数, $I_{b}$ : 断面二次モ一メント, $\kappa_{b}$ : 有効せん断係数,

$G_{b}:$ せん断弾性係数.

ただし、式(7)は $\left(1-b_{0}^{2} r_{0}^{2} s_{0}^{2}\right) \geqq 0$ の条件の元に得られる式である。(1$\left.b_{0}{ }^{2} r_{0}{ }^{2} s_{0}{ }^{2}\right)<0$ のとさは、式(7)と若干表現が異なるが、実際に設計され る梁の寸法を考虑すれば、ほとんどが $\left(1-b_{0}{ }^{2} r_{0}{ }^{2} s_{0}{ }^{2}\right) \geqq 0$ となるので、こ こではその場合のみを解析の対象とする。

一方、Timoshenko 梁の雨端をそれぞれ鈶直バネ㓮性 $K_{a}, K_{b}$ 及び回転 バネ剛性 $R_{a}, R_{b}$ を有する各バネで支持する時、境界条件は次式のよう に与えられる。

$$
\begin{aligned}
& \left.K_{a} W_{b}\right|_{x=0}-\kappa_{b} G_{b} A_{b}\left(W_{b},\left.{ }_{x}\right|_{x=0}-\left.\Theta_{x}\right|_{x=0}\right)=0 \\
& \left.R_{a} \Theta_{x}\right|_{x=0}-E_{b} I_{b} \Theta_{x},\left.\left.\right|_{x}\right|_{x=0}=0 \\
& \left.K_{b} W_{b}\right|_{x=L}+\kappa_{b} G_{b} A_{b}\left(W_{b},\left.{ }_{x}\right|_{x=L}-\left.\Theta_{x}\right|_{x=L}\right)=0 \\
& \left.R_{b} \Theta_{x}\right|_{x=L}+E_{b} I_{b} \Theta_{x},\left.{ }_{x}\right|_{x=L}=0
\end{aligned}
$$

式(11)に式(7)を代入すれば $C_{1} \sim C_{4}$ を固有ベクトルとする次の同次方 程式にまとめることができる。

$$
\sum_{j=1}^{4} A_{i j} C_{j}=0 \quad(i=1 \sim 4)
$$

ただし、 $A_{i j}$ の各成分の内容は次の通りである。

$A_{11}=-\kappa_{b} G_{b} A_{b}\left(\frac{P_{0}}{L}-k_{1}\right), A_{12}=K_{a}, A_{13}=-\kappa_{b} G_{b} A_{b}\left(\frac{q_{0}}{L}-k_{2}\right), A_{14}=K_{a}$,

$A_{21}=R_{a} k_{1}, A_{22}=E_{b} I_{b} k_{1} \frac{p_{0}}{L}, A_{23}=R_{a} k_{2}, A_{24}=-E_{b} I_{b} k_{2} \frac{q_{0}}{L}$, 
$A_{31}=K_{b} \sin p_{0}+\kappa_{b} G_{b} A_{b}\left(\frac{p_{0}}{L}-k_{1}\right) \cos p_{0}$,

$A_{32}=K_{b} \cos p_{0}+\kappa_{b} G_{b} A_{b}\left(-\frac{p_{0}}{L}+k_{1}\right) \sin p_{0}$,

$A_{33}=K_{b} \sinh q_{0}+\kappa_{b} G_{b} A_{b}\left(\frac{q_{0}}{L}-k_{2}\right) \cosh q_{0}$,

$A_{34}=K_{b} \cosh q_{0}+\kappa_{b} G_{b} A_{b}\left(\frac{q_{0}}{L}-k_{2}\right) \sinh q_{0}$,

$A_{41}=R_{b} k_{1} \cos p_{0}-E_{b} I_{b} k_{1} \frac{p_{0}}{L} \sin p_{0}, A_{42}=-R_{b} k_{1} \sin p_{0}-E_{b} I_{b} k_{1} \frac{p_{0}}{L} \cos p_{0}$,

$A_{43}=R_{b} k_{2} \cosh p_{0}+E_{b} I_{b} k_{2} \frac{q_{0}}{L} \sinh q_{0}, A_{44}=R_{b} k_{2} \sinh q_{0}+E_{b} I_{b} k_{2} \frac{q_{0}}{L} \cosh q_{0}$.

$\omega_{n}$ は式(12)より得られる特性方程式の根である。この特性方程式は 超越方程式となるが、ここでは行列式がゼロとなる条件によって根を 求めている。

こうした形状関数の利用により、バネ剛性の值を変化させるだけで、 平板解析における固定支持、単純支持、自由端、及び、それらの中間 の固定度を表わす境界条件を全て表現することができる。ただし、自 由端を含む平板を解析する場合には形状関数の低次モ一ドに剛体変形

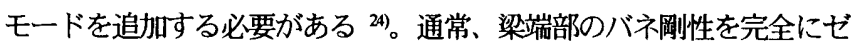
口にして式(7)の未定係数を求めると剛体変形モードは得ることができ ないが、梁端部に微少な量の鈶直バネ剛性を与えることにより、平板 解析に必要な風体变形モ一ドを自動的に含めることができる ${ }^{\circ}$ 。

Fig.2 はそれを実際の数值例によって示したものである。両端を同じ 剛性の鈶直バネで支持するものとし(両端の回転バネ哃性はゼ口)、そ の鈶直バネ剛性をゼロから無限大まで、すなわち両端自由端から両端 単純支持へ之徐々に変化させた場合、梁の 1 次固有振動数がどう変化 するかを表わしている。なお、横軸には無次元化された鈶直バネ剛性 の值、縦軸には式(10)に示される無次元化された 1 次固有円振動数 $b_{0}^{2}$ の值を採つている。Fig.3 は、梁両端部が Fig.2 に示す点 A, B, C の各鈶

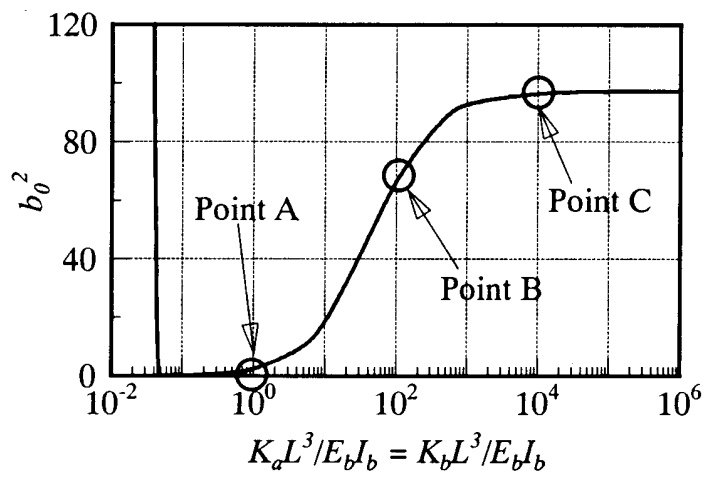

Fig.2 Variation of dimensionless frequencies for Timoshenko beam with respect to the degree of elastic restraint against translation
直バネ剛性を持つ時における Timoshenko 梁の 1〜3 次モードの鈶直変 位分布を示している。

Fig.2において、無次元化バネ㓮性がゼロに近い所で、 $b_{0}{ }^{2}$ の值力゙垂直 に上昇する現象が見られる。上昇する前は、Fig.3 (a)に示すように、1 次と 2 次に剛体変形に極めて近いモード形か現われる。上昇した後は、 1 次モードが Fig.3 (a)で示す 3 次モードと一致し、剛体変形モ一ドが 消失する。すなわち、Fig.2 で示す点 $\mathrm{A}$ 近傍の值を鈶淔バネ㴊性に選 ぶことにより、近似的ではあるが平板解析における自由端を表現でき る。両端単純支持の境界条件は鈶直バネ㓮性を大きくすることにより、 Fig.2 (c)に示すように安定してその振動モード形を表わすことができる。 Fig.3 (b) は、(a)と(c)の中間的な振動モード形となっている。ここでは 両端自由端について示したが、片方の端部が単純支持や固定支持の場 合についても同様に取り扱うことができる。

\section{3. 簡易解析法の精度の検証}

本簡易解析の妥当性と計算精度を検証するため、既往の研究及び FEMの解と比較する。以下にその比較例を示す。

\section{1 自由振動解析}

（1）固定支持・単純支持・自由端を組み合わせた正方形 Mindlin 平板

本簡易解析の特徴である周辺バネ支持の境界条件を利用して、その バネ剛性を変化させることにより、固定支持、単純支持、自由端を表 現する問題を考える。等方性平板に対して形状は正方形とし、板厚を 表わすパラメー夕は $h / a=0.01,0.1$ の 2 通りを用いる。比較は文献 21$) に$ 示される 1 6 次モードの次式で表わされる無次元化固有円振動数パ

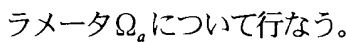

$$
\Omega_{a}=\omega_{a} a \sqrt{2(1+v) \rho_{0} / E}
$$

ただし、 $\omega_{a}$ は正方形 Mindlin 平板の固有円振動数、レ,Eはそれぞれ等 方性板のポアソン比、ヤング係数を意味する。また、物性值として、 $\nu=0.3, \kappa=0.822$ を用いる。

文献 21)では本簡易解析と同様の Rayleigh-Ritz 法を採用しているが、 形状関数には両端の境界条件を完全に満足させた Timoshenko 梁関数 を用いており、Kirchhoff 理論等と比較してその解の妥当性を検証して いる。ここで扱う境界条件の種類は、SS-C-SS-C, SS-C-SS-SS, SS-C-SSF, C-C-C-Fの 4通りである。ただし、CはClamped、SSはSimply Supported、 F はFree を意味し、Fig.1 (b)に示す境界 A, D, B, Cの順に示している。 形状関数の級数の項数は文献 21 )に合わせて共に $5 \times 5$ とする。

比較結果を Table 1 に示す。何れの境界条件のケースも解は高次モ一 ドまで良く一致しており、本解で用いた周辺バネ支持の種々の境界条 件に対する適用性とその精度が確認できる。

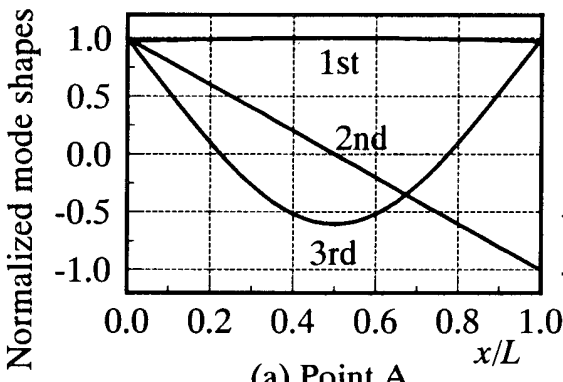

(a) Point $\mathrm{A}$

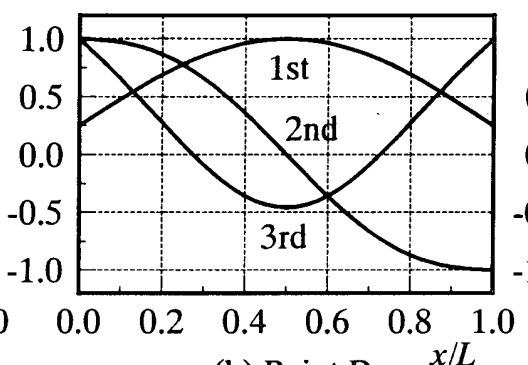

(b) Point B

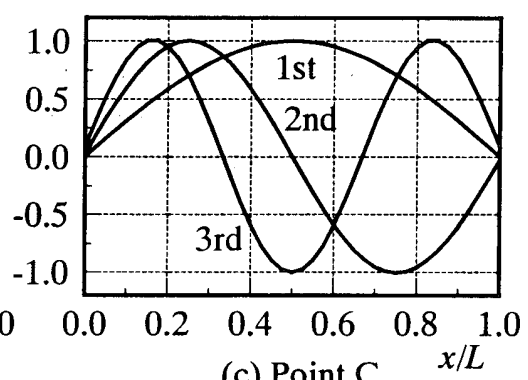

(c) Point $\mathrm{C}$

Fig.3 Normalized mode shapes of Timoshenko beam with elastic restraint against translation 
Table 1 Frequency parameters $\Omega_{a}$ of square Mindlin plate with various boundary conditions

(a) Boundary condition SS-C-SS-C

\begin{tabular}{|c|c|c|c|c|}
\hline \multirow{2}{*}{$\begin{array}{c}\text { Mode } \\
\text { sequences }\end{array}$} & \multicolumn{2}{|c|}{$h / a=0.01$} & \multicolumn{2}{c|}{$h / a=0.1$} \\
\cline { 2 - 5 } & Present & Ref.(21) & Present & Ref.(21) \\
\hline 1 & 0.1414 & 0.1411 & 1.305 & 1.302 \\
2 & 0.2670 & 0.2668 & 2.400 & 2.398 \\
3 & 0.3386 & 0.3377 & 2.895 & 2.888 \\
4 & 0.4616 & 0.4608 & 3.856 & 3.852 \\
5 & 0.4981 & 0.4979 & 4.238 & 4.237 \\
6 & 0.6304 & 0.6279 & 4.951 & 4.939 \\
\hline
\end{tabular}

(b) Boundary condition SS-C-SS-SS

\begin{tabular}{|c|c|c|c|c|}
\hline \multirow{2}{*}{$\begin{array}{c}\text { Mode } \\
\text { sequences }\end{array}$} & \multicolumn{2}{|c|}{$h / a=0.01$} & \multicolumn{2}{c|}{$h / a=0.1$} \\
\cline { 2 - 5 } & Present & Ref.(21) & Present & Ref.(21) \\
\hline 1 & 0.1154 & 0.1153 & 1.094 & 1.092 \\
2 & 0.2520 & 0.2521 & 2.299 & 2.298 \\
3 & 0.2861 & 0.2858 & 2.546 & 2.543 \\
4 & 0.4200 & 0.4199 & 3.618 & 3.616 \\
5 & 0.4885 & 0.4889 & 4.188 & 4.187 \\
6 & 0.5522 & 0.5533 & 4.548 & 4.543 \\
\hline
\end{tabular}

(c) Boundary condition SS-C-SS-F

\begin{tabular}{|c|c|c|c|c|}
\hline \multirow{2}{*}{$\begin{array}{c}\text { Mode } \\
\text { sequences }\end{array}$} & \multicolumn{2}{|c|}{$h / a=0.01$} & \multicolumn{2}{c|}{$h / a=0.1$} \\
\cline { 2 - 5 } & Present & Ref.(21) & Present & Ref.(21) \\
\hline 1 & 0.06225 & 0.06217 & 0.6148 & 0.6033 \\
2 & 0.1613 & 0.1612 & 1.506 & 1.495 \\
3 & 0.2045 & 0.2045 & 1.951 & 1.900 \\
4 & 0.3075 & 0.3075 & 2.757 & 2.744 \\
5 & 0.3527 & 0.3528 & 3.076 & 3.073 \\
6 & 0.4438 & 0.4438 & 3.872 & 3.855 \\
\hline
\end{tabular}

(d) Boundary condition C-C-C-F

\begin{tabular}{|c|c|c|c|c|}
\hline \multirow{2}{*}{$\begin{array}{c}\text { Mode } \\
\text { sequences }\end{array}$} & \multicolumn{2}{|c|}{$h / a=0.01$} & \multicolumn{2}{c|}{$h / a=0.1$} \\
\cline { 2 - 5 } & Present & Ref.(21) & Present & Ref.(21) \\
\hline 1 & 0.1174 & 0.1171 & 1.100 & 1.089 \\
2 & 0.1954 & 0.1951 & 1.770 & 1.758 \\
3 & 0.3103 & 0.3093 & 2.691 & 2.673 \\
4 & 0.3740 & 0.3740 & 3.220 & 3.216 \\
5 & 0.3940 & 0.3931 & 3.334 & 3.318 \\
6 & 0.5700 & 0.5695 & 4.619 & 4.615 \\
\hline
\end{tabular}

\section{（2）周辺固定支持された梁付矩形 Mindlin 平板}

周辺固定支持された矩形 Mindlin 平板を数本の Timoshenko 梁で補剛 する問題を考える。解析モデルは Fig.4 に示す2通りである。1つ目 は $x$ 軸方向の梁が板中央に 1 本ある夕イプ(Model A)、2 つ目は $x$ 及び $y$ 軸方向にそれぞれ梁が等間隔に 2 本づつある夕イプ(Model B)である。 解析結果は pb-2 Rayleigh-Ritz 法 25)を用いた文献 26)と比較し、同文献 に示される 1〜6 次モードの次式で表わされる無次元化固有円振動数 パラメータ $\Omega_{b}$ について行なう。

$$
\Omega_{b}=\left(\omega_{b} b^{2} / \pi^{2}\right) \sqrt{\rho_{0} h / D}
$$

ただし、 $\omega_{b}$ は梁付矩形 Mindlin 平板の固有円振動数、 $D$ は等方性板の 曲け剛性である。梁付平板の緒元は、一部 Fig.4 に示す記号を用いて $a / b=1,2 、 f / h=1.5 、 h / b=0.05 、 e / b=0.05 、 \nu=0.3 、 \kappa=5 / 6$ である。なお、 本解で用いる形状関数の級数の項数は $10 \times 10$ とする。

比較結果を Table 2 に示す。何れのケースもほぼ一致した解が得られ ており、梁付平板に対する本解の妥当性が確認できる。

\section{2 時刻歴応答解析}

解析モデルは、周辺自由端で四隅点の鈶直变位を拘束した等方性の 正方形床スラブとする。外力は、一定の大きさの集中荷重が平板の中

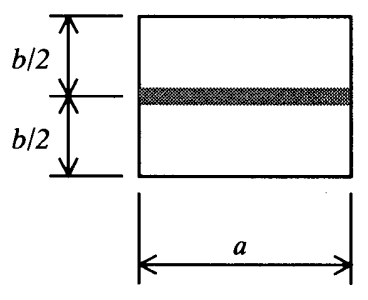

Model A

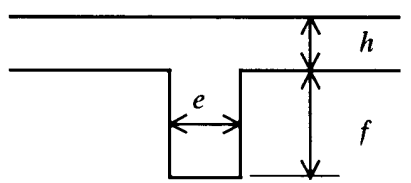

A cross section of stiffened plate

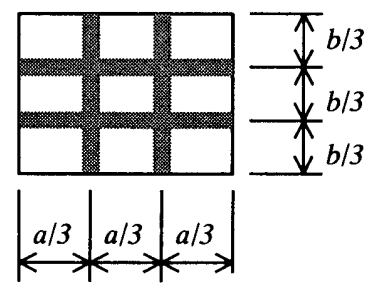

Model B

$$
A_{b}=e f
$$$$
I_{b}=\frac{e f^{3}}{12}+e f\left(\frac{h+f}{2}\right)^{2}
$$$$
J_{b}=\frac{e f^{3}}{12}+\frac{f e^{3}}{12}
$$

Fig.4 Numerical examples of rectangular stiffened plate with boundary condition C-C-C-C

Table 2 Frequency parameters $\Omega_{b}$ of rectangular stiffened Mindlin plate with boundary condition C-C-C-C

(a) Model A

\begin{tabular}{|c|c|c|c|c|}
\hline \multirow{2}{*}{$\begin{array}{c}\text { Mode } \\
\text { sequences }\end{array}$} & \multicolumn{2}{|c|}{$a / b=1$} & \multicolumn{2}{c|}{$a / b=2$} \\
\cline { 2 - 5 } & Present & Ref.(26) & Present & Ref.(26) \\
\hline 1 & 4.637 & 4.639 & 2.434 & 2.431 \\
2 & 7.048 & 7.138 & 3.801 & 3.786 \\
3 & 9.695 & 9.628 & 5.964 & 5.977 \\
4 & 10.30 & 10.40 & 6.133 & 6.218 \\
5 & 11.99 & 11.96 & 6.846 & 6.931 \\
6 & 15.31 & 15.41 & 8.036 & 8.120 \\
\hline
\end{tabular}

(b) Model B

\begin{tabular}{|c|c|c|c|c|}
\hline \multirow{2}{*}{$\begin{array}{c}\text { Mode } \\
\text { Sequences }\end{array}$} & \multicolumn{2}{|c|}{$a / b=1$} & \multicolumn{2}{c|}{$a / b=2$} \\
\cline { 2 - 5 } & Present & Ref.(26) & Present & Ref.(26) \\
\hline 1 & 5.627 & 5.656 & 3.444 & 3.455 \\
2 & 10.53 & 10.50 & 4.667 & 4.671 \\
3 & 10.53 & 10.50 & 6.408 & 6.454 \\
4 & 14.55 & 14.64 & 7.717 & 7.739 \\
5 & 17.04 & 18.00 & 8.737 & 8.810 \\
6 & 17.26 & 18.03 & 9.074 & 9.146 \\
\hline
\end{tabular}

Table 3 Frequencies $(\mathrm{Hz})$ of square Mindlin plate four corners are simply spported with boundary condition F-F-F-F

\begin{tabular}{|c|c|c|c|c|}
\hline \multirow{2}{*}{$\begin{array}{c}\text { Mode } \\
\text { sequences }\end{array}$} & \multicolumn{3}{|c|}{ Present } & FEM \\
\cline { 2 - 4 } & $6 \times 6$ & $8 \times 8$ & $10 \times 10$ & \\
\hline 1 & 10.49 & 10.42 & 10.37 & 10.33 \\
2 & 23.71 & 23.43 & 23.22 & 23.05 \\
3 & 23.71 & 23.43 & 23.22 & 23.05 \\
4 & 30.81 & 30.79 & 30.78 & 30.90 \\
5 & 54.92 & 54.20 & 53.73 & 53.99 \\
6 & 63.53 & 62.63 & 62.06 & 62.00 \\
\hline
\end{tabular}

央線 $(x$ 軸力向)を端から端に水平方向に移動する。そして、TMD が無 い場合(Case-A)と TMD が床中央に設置された場合(Case-B)について考 え、林中央の時刻歴応答変位を、FEM（汎用コード MARC 使用）の 結果と比較する。FEM では矩形厚肉シェル要素を用い、 $18 \times 18$ にメ ッシュ分割する。この分割数は十分な精度を保証できるものである。 床板の諸元は次の通りである。

$a=b=9 \mathrm{~m}, h=90 \mathrm{~cm}(h / a=0.1)$

$E=2.1 \times 10^{7} \mathrm{kN} / \mathrm{m}^{2} 、 \nu=1 / 6 、 \rho_{0}=2.4 \mathrm{t} / \mathrm{m}^{3} 、 \kappa=5 / 6$

TMD は最適同調するよう值を定め2、その諸元は次の通りである。 $m_{1}=0.96 \mathrm{t} 、 k_{I}=3984 \mathrm{kN} / \mathrm{m} 、 h_{I}($ 減衰比 $)=0.061$ 


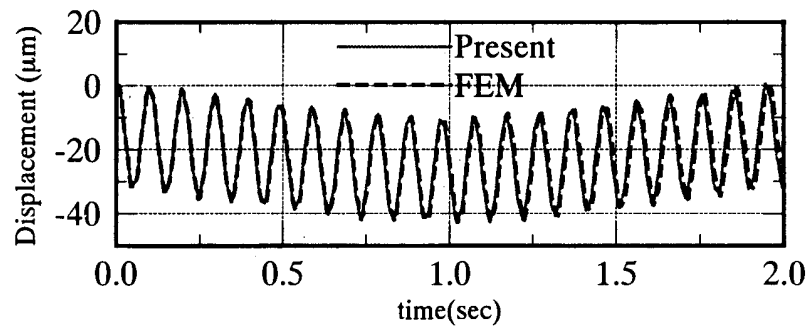

(a) Without a TMD (Case-A)

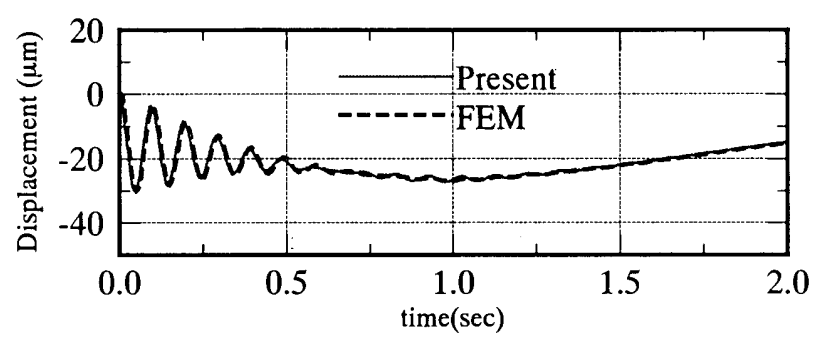

(b) With a TMD (Case-B)

Fig.5 Comparisons of displacement at the center of the floor subjected to a moving load

移動荷重の速度は $4.5 \mathrm{~m} / \mathrm{s}$ とし、座標 $(0 \mathrm{~m}, 4.5 \mathrm{~m})$ から $(9 \mathrm{~m}, 4.5 \mathrm{~m})$ まで移 動する。荷重值は $9.8 \mathrm{kN}$ と一定とする。FEM では集中荷重をそれが作 用する近傍の 2 点に等価節点力として近似的に与える。床スラブ内部 の減衰比は Rayleigh 型減衰で与元、TMD が無い状態における床スラ ブの 1 次と 2 次の振動モードに対し、それぞれ3\%とする。

まず、本モデルの固有振動数の值を Table 3 に示す。本解において自 由振動解析で用いた形状関数の級数の項数は $6 \times 6 、 8 \times 8 、 10 \times 10$ の 3 通りで、 $10 \times 10$ の時が FEM の解と最も良く一致しており、時刻歷 応答解析ではその項数を用いる。

次に床中央の時刻尓応答変位を Fig.5 (a), (b)に示す。図(a)は TMD の 無い場合であり、移動荷重の速度が比較的低いにもかかわらず、その 影響で本中央が大きく振動している。図(b)はTMDがある場合であり、 0.5 秒後には移動荷重の動的効果による摇れが大きく抑えられ、以降静 的な荷重を受けた時のたわみ分布と一致する結果となっている。何れ のケースも本解と FEM の解はほぼ一致しており、点支持、TMD、及 ひ移動荷重を同時に考慮した解析に対し、本解の妥当性が碓認できる。

\section{4. 床スラプの有効質量}

環境振動の対策として床スラブに TMD を設置することは有効であ る。TMD の設計では床スラブの有効質量 (一般化質量) の推定と TMD の有効な設置場所となる振動モードの腹の位置を、梁付スラブにおい て推定することが重要である。こうした TMD の設計支援を目的とし て、本簡易解析による床スラブの有効質量の計算例を示す。

梁付 Mindlin 平板の有効質量 $M_{e}$ は、次式により求めることができる。

$$
M_{e}=\sum_{m=1} \sum_{n=1} \phi_{m n} \sum_{i=1} \sum_{j=1} M_{m i j} \phi_{i j}
$$

ただし、 $M_{m \text { mi் }}$ は式(6)から導かれるマス・マトリクス成分、 $\phi_{m}$ は最大 值を 1 に基準化したモードベクトルである。 $i, j$ はそれぞれ $m, n$ に対 応した級数の指標である。この式(15)を用いて、種々の境界条件下に おける矩形平板の有効質量、及び、周辺単純支持された日の字形梁付 矩形平板の有効質量をパラメトリックに計算し、図にまとめる。なお、

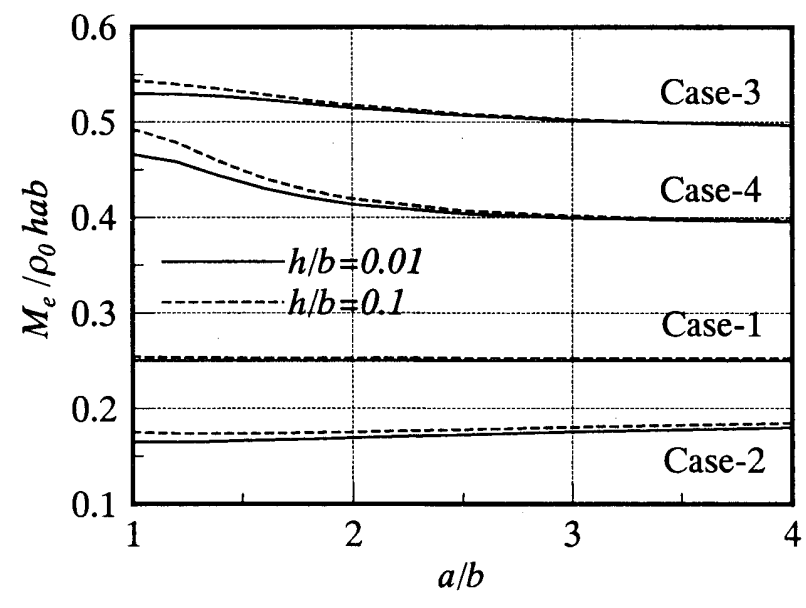

Fig.6 Variation of effect mass for rectangular Mindlin plate under various boundary conditions

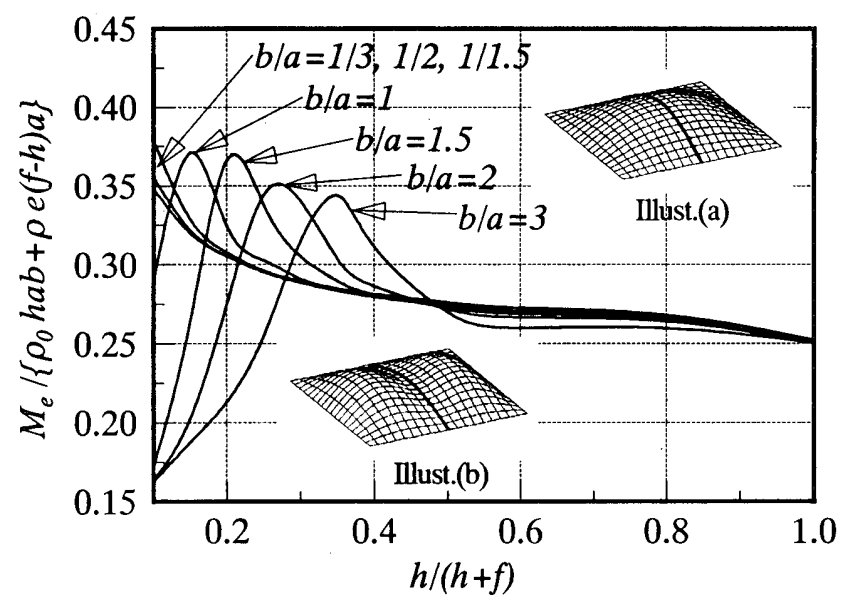

Fig.7 Variation of effect mass for stiffened rectangular Mindlin plate with an intermediate beam and fully simply supported edges

本計算で用いる形状関数の級数の項数は $8 \times 8$ とする。

\section{1 矩形 Mindlin 平板のスパン比と板厚の影䈉}

周辺単純支持(Case-1)、周辺固定支持(Case-2)、周辺自由端で四隅点 の鈶直变位を拘束(Case-3)、及び、周辺ガイド支持(回転成分のみ拘束) で四隅点の鈶直変位を拘束(Case-4)した 4 つの境界条件について考える。 1 次モードに対する有効質量を平板の全質量で割った值とスパン比 $a / b$ $(=1 \sim 4)$ 及び板厚比 $h / b(=0.01,0.1)$ との関係を Fig.6 に示す。図中、実線 は $h / b=0.01$ のときを示しており、Kirchhoff 仮定の結果とほぼ一致した ものである。

四隅点の鈶直变位を拘束したタイプ(Case-3, 4)では、周辺の鈶直変位 を拘束したタイプ(Case-1，2)に比べて、無次元化した有効質量の值が 2 倍程度大きい。また、何れのケースもスパン比及び板厚比に対して大 きな変化は無いが、Case-4が最もそれらの影響を受けている。

\section{2 梁付矩形 Mindlin 平板の梁成とスパン比の影響}

平板の中央に 1 本の梁を有する日の字形梁付矩形平板を考える。境 界条件は周辺単純支持とする。1 次モ一ドに対する有効質量を梁付平 板の全質量で割った值と梁成及びスパン比 (b/a)との関係を Fig.7 に示 す。梁の断面寸法は Fig.4 に示す記号で表示している。また、梁幅 $e$ は スパン長 $b$ の $1 / 20$ とし、梁の断面性能は図心位置で計算している。 


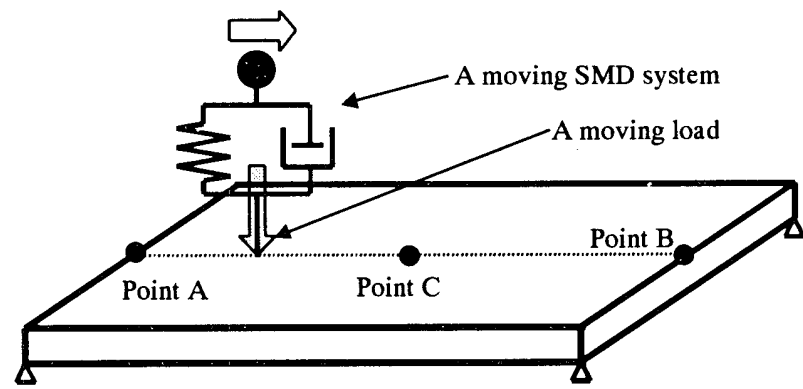

Fig.8 Examples of square Mindlin plate with a SMD system subject to a moving load (Case-b)

Fig.7において $b / a=1,15,2,3$ のとき、上に凸のピーク值が存在する。 ピーク值の右側すなわち梁成が小さくなる側では、Fig.7 中の振動モ一 ドを表わす Illust.(a)に示すように 1 次モ一ドの最大変位は梁上に存在 している。その左側すなわち梁成が大きくなる側では、Fig.7 中の振動 モ一ドを表わす Illust.(b)に示すように 1 次モードの最大変位は梁を挟 んで両方の平板部分に存在している。従って、日の字形梁付スラブに おいて梁成及びスパン比との関係により、モードの腹が梁上に出るの か、あるいは板部に出るのかを推定することができる。この事は、床 スラブの噮境振動対策を考える上で重要である。

\section{5. 移動荷重及ひ移動 SMD 系の影響}

移動荷重や移動 SMD 系が床振動に与える影響を考察するため、2 種類の境界条件、すなわち周辺単純支持(Case-a) と周辺自由端で四隅点 の鈶直変位を拘束したもの (Case-b)について、幾つかの計算例を示す。

Case-b の解析モデルの概要を Fig.8 に示す。移動荷重のみを考慮する 場合は同図で SMD 系を取り除いたモデルとなる。移動荷重及び移動 $\mathrm{SMD}$ 系は境界辺中央の点 $\mathrm{A}$ から反対側の境界辺中央の点 $\mathrm{B}$ まで一定 速度で移動する。荷重の大きさは一定值とし、平板内部の減言は無い ものとする。Mindlin 平板の形状及び物性值は次の通りで、ここでは Case-a, b 共に約 $5.0 \mathrm{~Hz}$ となるように設定している。

Case-a : $a=b=9 m, h=15 \mathrm{~cm}$

Case-b : $a=b=9 m, h=42.1 \mathrm{~cm}$

$E=2.1 \times 10^{7} \mathrm{kN} / \mathrm{m}^{2}, \nu=1 / 6, \rho_{0}=2.4 \mathrm{t} / \mathrm{m}^{3}, \kappa=5 / 6$ (Case-a, b 共通)

また、計算結果を表示するために次の記号を定義する。

$T_{I}$ : 平板の 1 次固有周期 $\fallingdotseq 0.2$ 秒 $), t:$ 時間,

$\tau:$ 移動荷重が点 A から点 B に達するのに要する時間,

$w_{s}$ : 点 Cに集中荷重を作用させた時の点 $\mathrm{C}$ の静的たわみ量,

$w_{d}$ : 移動荷重下における点 Cの動的たわみ量,

$f_{o}: \mathrm{SMD}$ 系の振動数, $M$ : 平板の全質量, $m_{0}$ : 付加質量.

なお、本計算では形状関数の級数の項数は $6 \times 6$ とする。

\section{1 移動荷重のみの影徂}

付加質量の影響を無視し、移動荷重の速度を $T_{1} / \tau=0.025,0.1,0.5,1.0$ $(1.125,4.5,22.5,45 \mathrm{~m} / \mathrm{s})$ の 4 通りについて、点 Cでの静的たわみに対す る動的たわみの比、すなわち $w_{d} / w_{s}$ の時間変化を鉿直下向き方向を負 として Fig.9 に示す。Case-a は既往の研究で示される結果 8と同等であ り、梁上の移動荷重の問題 ${ }^{11}$ と類似した結果である。低速度 $1.125,4.5 \mathrm{~m} / \mathrm{s}$ の場合、たわみ比の最大值はほぼ 1.0 であり動的効果は小さく、それ らより高速度の場合では動的効果は大きい。一方、Case-b では低速度 $1.125,4.5 \mathrm{~m} / \mathrm{s}$ においてもたわみ比が 1.5 を超える值を示している。これ

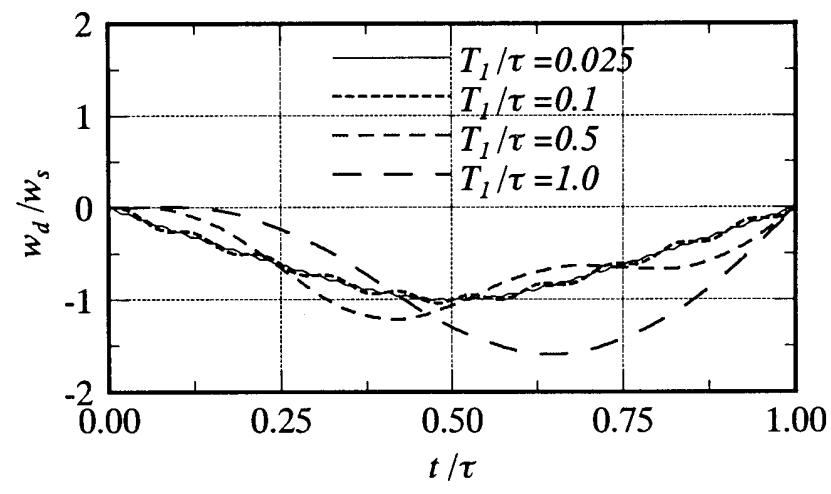

(a) Boundary condition SS-SS-SS-SS (Case-a)

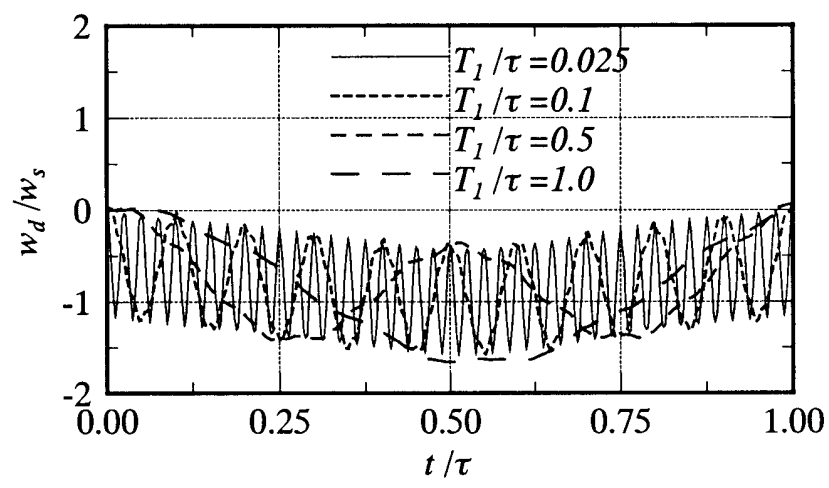

(b) Boundary condition F-F-F-F and 4 corners simply supported (Case-b)

Fig.9 Dynamic magnification factors for a moving load

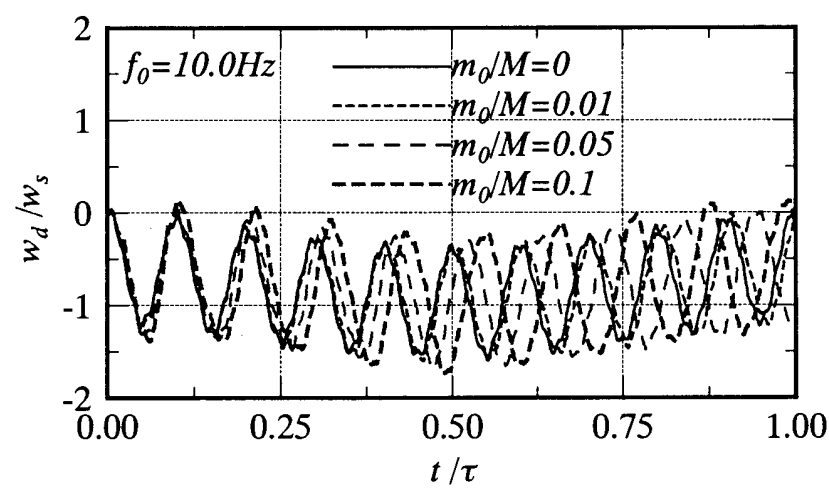

(a) Influence of an additional mass in the SMD system (Case-b)

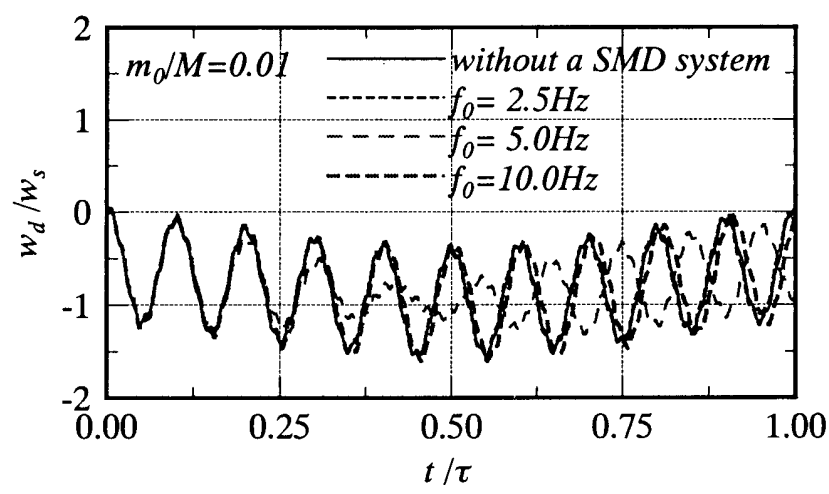

(b) Influence of a frequncy in the SMD system (Case-b)

Fig.10 Dynamic magnification factors for a moving load and a moving SMD system 
は Fig.8 の点 A 及び点 B の位置が自由端になっていることが原因と考 えられる。大スパンの床スラブは周辺単純支持よりも四隅点支持の状 態に近いと考えられるので、環境振動の問題を考える場合、注意を要 する現象である。また、Case-b においては Case-a で見られる程、移動 速度の影響は大きくない。

\section{2 移動荷重及ひ移動 SMD 系の影䭗}

5.1 節で示した Case-b の移動速度 $T_{1} / \tau=0.1$ につて、SMD 系を付 加した問題を考える。平板の 1 次固有振動数が約 $5.0 \mathrm{~Hz}$ であるのに対 し、付加する SMD 系の振動数を $f_{o}=2.5,5.0,10.0 \mathrm{~Hz}$ の 3 通り、及び、 付加質量と平板全質量の比を $m_{d} d M=0.01,0.05,0.1$ の 3 通りとし、それ らの影響を調べる。なお、ダッシュポットの減衰比は $1 \%$ とする。

動的たわみ比 $w_{d} / w_{s}$ の時間変化を Fig.10 (a), (b)に示す。図(a)は SMD 系の振動数を $10.0 \mathrm{~Hz}$ と固定し、質量比の変化の影響を示している。 付加質量が大きくなると、平板と SMD 系を一体として捉えた振動系 の周期が長くなっているのが判る。また、たわみ比は付加質量が大き くなると、やや大きくなる傾向が見られる。図(b)は質量比を $m_{d} / M=0.01$ と固定し、SMD 系の振動数の変化による影響を示している。SMD 系 の振動数が平板の 1 次固有振動数と等しい時、林スラブ中央近傍でた わみ比が小さくなる傾向が見られる。その他の振動数については顕著 な差は見られない。

\section{6. 結ひ}

環境振動設計支援のための床スラフ簡易解析手法について述べた。 床スラブは直交異方性を有し、Timoshenko 梁で補強された矩形 Mindlin 平板にモデル化している。本解析手法は Rayleigh-Ritz 法を用い、形状 関数には両端がバネ支持された Timoshenko 梁関数を採用して、任意 位置での点支持を扱うことができる特徵を持ち、現実に即した境界条 件の設定が可能である。また、振動の低减を目的とした TMD や床ス ラブ上を水平方向に移動する物体の動的な効果も考慮できる。

本簡易解析の妥当性は既往の研究及び FEM の解之比較することに より確認した。形状関数の級数の項数に関しては、条件による違いは あるが $10 \times 10$ 程度でほぼ収束した解が得られる。しかし、実際の床 スラブ解析では境界条件が解に最も大きな影響を与え、それに比べる と級数の項数による影響は小さい。実用的には級数の項数は $6 \times 6$ 程 度で十分と考えられる。

また、本論文の計算例より得られた床スラブの有効質量及び移動物 体の問題に関する知見を以下に要約する。

\section{○有効質量の問題について}

- 矩形平板の全質量に対する 1 次モ一ドの有効質量の比は、板厚やス パン比の影響を若干受けるが、境界条件による影響の方が大きく、 林スラブ解析において境界条件の設定が重要となる。

- 日の字形梁付平板の全質量に対する 1 次モ一ドの有効質量の比につ いては、梁成及びスパン比から受ける影響が比較的大きく、Fig.7 が床スラブの環境振動の対策を考える上で参考となる。

\section{৩移動物体の問題について}

・ 床スラブ解析において、床スラブ周辺の銛值変位を拘束した境界条 件下における低速度 (人やフォークリフトを想定)の時の移動荷重 による動的効果は小さく、その影響は無視できる。しかし、四隅点 支持の条件下では移動荷重が低速度の時でも動的効果が大きく、移 動荷重の影響は無視できない。
謝辟 本研究を進めるに当たり、株式会社フジ夕技術研究所 中山昌尚 博士には貴重なご意見を頂きました。記して謝意を表します。

\section{参考文献}

1) 櫛田 裕: 床の振動性状と最適環境を考慮した設計法に関する研究 一床 振動評価基準に関する考察-, 日本建築学会計画系論文報告集, 第 404 号, pp.1-7, 1989.10

2) 松浦 章: パッシプ型 TMD(Tuned Mass Damper)の適用事例, 日本建築学 会環境工学委員会環境振動小委員会, 第 15 回環境振動シンポジウム, pp.25-29, 1997.1

3) 櫛田 裕：「環境振動工学入門」, 理工図書, 1997

4) 鈴木敏夫, 大山秀美, 田中清: 居住㦿の振動予測之評価に関する研究 (そ の 1,2 ), 日本建築学会大会学術講演梗概集 D1,pp.347-350, 1995

5) 中山昌尚, 藏 正幸, 鈴木敏夫, 増田圭司 : フォークリフト走行に伴う 動的荷重の害測，日本建築学会大会学術講演梗概集,pp.301-302, 1998.9

6) 鈴木健司 : 移動加振源による床振動の応答解析に関する検討, 日本建筑 学会大会学術講演梗概集, pp.303-304, 1998.9

7) 土木学会：「土木技術者のための振動便覧」，1966

8) D.M.Yoshida and W.Weaver, JR : Finite-Element Analysis of Beams and Plates with Moving Loads, IABSE, 31(1), pp.179-195, 1971

9) S.P.チモシェンコ, D.H.ヤング：「構造力学」, ブレイン図書, 1975

10) 藤掛一典, 大野友則, 西岡隆 : 走行質量の影響を考慮したア一千橋の動 的応答，士木学会論文集 第 374 号 / I -6, pp.389-398, 1986.10

11) Y.-H.Lin and M.W.Trethewey : Finite Element Analysis of Elastic Beams Subjected to Moving Dynamic Loads, Journal of Sound and Vibration, 135(2), pp.323-342, 1990

12) KT.Sundara Raja Iyenger and K.S.Jagadish : Dynamic Response of Highway Bridges to Moving Loads, Puble. IABSE, Zurich, 30-II, pp.57-76, 1970

13) E.Esmailzadeh and M.Ghorashi : Vibration Analysis of a Timoshenko Beam Subjected to a Traveling Mass, Journal of Sound and Vibration, 199(4), pp.615628,1997

14) D.Y.Zheng, Y.KCheung, F.T.K.Au and Y.S.Cheng : Vibration of Multi-Span Non-Uniform Beams under Moving Loads by Using Modified Beam Vibration Function, Joumal of Sound and Vibration, 212(3), pp.455-467, 1998

15) H.Takabatake : Dynamic Analysis of Rectangular Plates with Stepped Thickness Subjected to Moving Loads Including Additional Mass, Journal of Sound and Vibration, 213(5), pp.829-842, 1998

16) Y. Kato and T. Honma : The Rayleigh-Ritz Solution to Estimate Vibration Characteristics of Building Floors, Joumal of Sound and Vibration, 211(2), pp.195-206, 1998

17) 加藤泰正, 本間俊雄, 中山昌尚, 増田圭司 : Rayleigh-Ritz 法を応用した 床スラブの微振動解析, 日本建策学会構造系論文集, No.518, pp.147-154, 1999.4

18) 加藤泰正, 本間俊雄 : 環境振動に関する床スラブ設計支援システムの開 発, 日本建築学会技術報告集 第7号,pp.169-174, 1999.2

19) E.Reissner : The Effect of Transverse Shear Deformation on the Bending of Elastic Plates, Journal of Applied Mechanics, pp.69-77, 1945.6

20) R.D.Mindlin : Influence of Rotatory Inertia and Shear on Flexural Motions of Isotropic, Elastic Plates, Journal of Applied Mechanics, pp.31-38, 1951.3

21) D.J.Dawe and O.L.Roufaeil : Rayleigh-Ritz Vibration Analysis of Mindlin Plates, Journal of Sound and Vibration, 69(3), pp.345-359, 1980

22) R.W.Traill-Nash and A.R.Collar : The Effects of Shear Flexibility and Rotatory Inertia on the Bending Vibrations of Beams, Quart. Joum. Mech. And Applied Math., Vol. VI, Pt.2, pp.186-222, 1953

23) T.C.Huang : The Effect of Rotatory Inertia and of Shear Deformation on the Frequency and Normal Mode Equations of Uniform Beams with Simple End Conditions, Journal of Applied Mechanics, 28, pp.579-584, 1961.12

24) Warburton : The Vibration of Rectangular Plates, Proceedings of the Institution of Mechanical Engineers, Vol.168, No.12, 1954

25) K.M.Liew and C.M.Wang : pb-2 Rayleigh-Ritz Method for General Plate Analysis, Eng Struct, Vol.15, No.1, pp.55-60, 1993

26) K.M.Liew, Y.Xiang, S.Kitiporchai and M.KLim : Vibration of Rectangular Mindlin Plates with Intermediate Stiffeners, Journal of Vibration and Acoustics, Vol.116, pp.529-535, 1994.10 